\title{
The Effect of Learning by Using Educative Game to Develop Plural Intelligence in Early Childhood
}

\author{
Mubiar Agustin ${ }^{a}$, Mubarok Somantri ${ }^{b}$ \\ aUniversitas Pendidikan Indonesia \\ bSekolah Tinggi Keguruan dan Ilmu Pendidikan Purwakarta \\ Corresponding e-mail: amubiar@yahoo.com
}

\begin{abstract}
This study investigates the most fundamental topic in early childhood. Sometimes, teachers push children to learn reading, writing, and arithmetic. In fact, not every child has the readiness to accept the learning. Another problem that often occurs in kindergarten's learning activities is the tendency of teachers who only refer to standard curriculum prescribed by the government. Therefore, many teachers are lazy and do not have creativity to make fun and entertaining learning for children. Based on this problem, a proper, integrative, and beneficial solution to all parties is needed. The solution to solve that problem is through the application of learning with educational games to pay tribute to the multiple intelligences of children. This study was conducted in one of kindergarten at Bandung city, involving 40 children. The method used in this study is quasi-experiment. The children were divided into an experimental group and a control group. The results show educational games can help to develop early childhood multiple intelligences.
\end{abstract}

Keywords: Educational games, early childhood multiple intelligences

\section{INTRODUCTION}

Early childhood education (ECD), especially kindergarten (TK) is an education for the children of the most fundamental, so this level of education was viewed as a time of the most valuable and decisive in life for children in the future. But in fact, education in kindergarten tend to still leave many shortcomings such as mistreatment made by teachers in learning activities. For example, teachers are learning to read and write imposing arithmetic to children although not every child has the preparedness to accept it. Not a few of education in kindergarten academic oriented by "forcing" activities of reading, writing and arithmetic as a drill, ironically in some cases demands to teach reading, writing and counting this is a formal request from parents to teachers, whereas Reber (1988) stated that errors of treatment/ stimulation in children will affect the occurrence of learning disorders, psychological and even in some cases resulted in the loss of valuable potential in children.

Another problem that common in learning activities in kindergarten is that teachers are only referring to a reference standard that has been specified of curriculum government so many teachers are lazy and do not have the creativity to make learning fun and entertaining for children.

One of the critical lessons developed from an early age is the plural intelligence based learning. Abraham (2001) explains plural intelligence should be developed early on include linguistic intelligence, musical intelligence, naturalistic intelligence, interpersonal intelligence, logical-mathematical intelligence, intrapersonal intelligence and spatial intelligence. In addition, support research related to the development of learning by applying intelligence in kindergarten them performed by Eliza (2005) where results showed that the activity of learning in kindergarten, in particular that are integrated to help improve the intelligence potential multi-child and developmental potential of intelligence plural for each child was different for each intelligence. Furthermore, the results of research conducted by Syaodih (2009) on the development of measurement tools plural intelligence of children of kindergarten. Based on the problems that developed above, of 
course, we need a proper solution, integrative and beneficial to all parties. Solutions offered to address these problems is through the application of learning by applying educational games to develop children's plural intelligence.

Why plural intelligence? For effective learning in kindergarten is not only focused on one aspect of development, but oriented towards the development of all aspects of child development (holistic).

Consequently in the learning process, teachers should give freedom to the child in learning activities and stimulate the child to develop one or multiple intelligences/plural intelligence to be more competent and skilled.

Even if study the direction of learning in kindergarten based curriculum in 2013 very clearly stated that the purpose of learning in kindergarten in addition to the development of character values through habituation is a range of potential development/intelligence of children through fun learning while playing.

Support research results related to the development of learning by applying intelligence and multiple scenes of children of kindergarten them performed by Eliza (2005) where results showed that the activity of learning in kindergarten, in particular that are integrated to help boost intelligence potential multi-child and developmental potential plural intelligence for each child was different for each intelligence.

Stimulation of plural intelligence is one of them can be framed in game activity. One game that is deemed appropriate to develop plural intelligence is the educational games because educational games useful for developing various kinds of intelligence, as well as personal development, close relationships between students and educators with children can also develop children's character value (Andang, 2006).

Play as the spirit of learning in early childhood education today much discarded. Though the play provides extraordinary energy for the development of the full potential of children, especially in developing a variety of intelligence. Therefore play to present something interesting and fun for children. For children, play is an activity that is serious, but exciting. Through play activities, a variety of job realized. Playing is an activity handpicked by children, for fun, not because it will receive a gift or compliment. Playing is one of the main tools into practice for growth. Play is the medium in which children try out, not only in his fantasy but also real active.
This research generally aims to find the effect of learning by using educational games to develop early childhood plural intelligence.

This study provides valid information on the impact of educational games are fun and cheer up to help develop early childhood plural intelligence that remarkable, especially in the group of kindergarten children.

\section{MULTIPLE INTELLIGENCES}

This research was supported by the main theory, that of plural intelligence. Plural intelligence is a term in the study of intelligence, initiated by an education expert from the United States named Howard Gardner. There is a diversity of translations of Multiple Intelligences, some people translate to multiple intelligences, multiple intelligences and multiple intelligences. In this paper which is used as a translation of multiple intelligences is plural intelligences.

The theory of multiple intelligences (multiple intelligences), not the first theory which states about their intelligence in addition to intelligence quotient (IQ) of the individual self. In line with the development of the human civilization, then began to happen paradigm shift in interpreting the meaning of intelligence.

The theory of multiple intelligences was developed in 1983 by Howard Gardner. Gardner argues that intelligence based on IQ testing, which is the traditional view, is very limited. Gardner proposed definition of the different intelligences to measure a broader scope of human potential, either children or adults. He divided it into eight (8) types of intelligence (Campbell, 1996).

The eighth intelligence could be owned by individuals, only in different stages. Besides, this intelligence does not stand alone, sometimes mixed with other intelligences (Rachmani, 2003).

Additionally, this intelligence does not stand alone, sometimes mixed with other intelligences (Jamaris, 2005). For example, when a smart kid singing as musical intelligence, it also usually be smart in gestures during follow and adjust to the rhythm/music sung. Another example is when a child was to become a surgeon, he needs visualspatial intelligence that stands out for using the scalpel, also the intelligence of his hand gestures for flexibility when using a knife.

In general description of plural intelligence in children and their indicators proposed by Gardner (2003) described as follows: 
- $\quad$ Linguistic intelligence/verbal is an ability to use words effectively, either oral or written. Linguistic intelligence in children refers to the ability to formulate thoughts clearly and are able to use this ability to competently through the words to express these thoughts in speaking, reading and writing (Lwin, 2005).

- Logical-mathematical intelligence is the ability to use numbers effectively and high in argued.

- Spatial intelligence is the ability to perceive the visual-spatial world accurately and ability to transform the "so" perceptions.

- Kinesthetic intelligence (bodily-kinesthetic) is the ability to use the whole potential of the body to express ideas and feelings.

- Musical intelligence is the ability to perceive, discriminate and express musical forms. Rachmawati (2005) explains that music can cause certain vibrations which doubtless will certainly lead to physical reactions.

- Interpersonal intelligence is the ability to perceive and discriminate in mode, specific intent, motivations and feelings of others.

- Intrapersonal intelligence is the ability to act adaptively on the basis of their own knowledge.

- The naturalist intelligence is an intelligence possessed by individuals to plants, animals and the natural environment. Children who have a naturalistic intelligence according to Armstrong (2003) tend liked the outdoors, familiar with the pet, and even spending their time near the pond or aquarium. Additionally children with high naturalistic intelligence tend to not afraid of picking insects and standing nearby (Musfiroh, 2004).

Gardner (2003) describes some of the advantages of multiple intelligences theory as follows: (a) have support multidisciplinary research that is anthropology, cognitive psychology, developmental psychology, psychometrics, biographical studies, animal physiology and neuroanatomical; and (b) when compared with other intelligences theory, the amount of intelligence in intelligence plural diverse, so it would seem "fairness" in determining the dominance of a particular intelligence to each individual.

According to Gardner (2003) intelligence is the ability to solve problems or produce products that are made in one or several cultures. In more detail Gardner outlines as follows: (a) the ability to resolve and find solutions to problems in real life: (b) the ability to generate new issues to be resolved: and (c) the ability to create something that would give rise to an award in one's culture.

Furthermore, according to Gardner intelligence is based on the biological potential, which is then expressed as a result of genetic factors and the environment affect each other. In general, normal individuals were able to show a mix of multiple intelligences. Intelligence is never found in its pure form. In contrast, the intelligence embedded in various systems of symbols, such as language, images, maps, musical notation and mathematical symbols.

Gardner (2003) explains that the plural intelligence (multiple intelligences) has the characteristics of a concept as follows: (a) all the intelligence is different, but all equal. In this sense, there is no intelligence that is better or more important than the other intelligences; (B) all the intelligence of human beings in the level that is not exactly the same. All intelligence can be explored, nurtured and developed optimally, (c) there are many indicators of intelligence in each intelligence. With practice, one can build strength and intelligence of diluting weaknesses, (d) all the different intelligences are working together to realize the activity by individuals. One activity may require more than one intelligence, and the intelligence can be used in various fields, (e) all types of intelligence are found in all / all cross cultures around the world and age groups, and (f) when a person mature, intelligence is expressed through achievement range of professions and hobbies. Logical-mathematical intelligence that started as the ability patterns in infancy and evolved into a symbolic mastery in childhood, for example, finally reaching maturity in the form of expression of the profession as a mathematician, accountants and scientists.

The essence of the theory of multiple intelligences by Gardner is appreciate the uniqueness of each individual, a wide variety of learning styles, embodies a number of models to assess them and almost unlimited ways to actualize themselves in this world.

Plural intelligence help teachers, parents or companion early childhood to know the strength and weaknesses of their children. But do not be quick to conclude that the child is fit to be athletes, accountant or mathematician, without giving him the opportunity to explore the world, working with his own skills and developing their potential.

Obviously the balance is one of the goals in the peeling Gardner about multiple types of intelligence. 
For that, he suggested teachers, parents or early childhood companion to help hone one prominent intelligence, such as musical intelligence, stimulating intelligence or linguistic mathematical logic. This means that a child's life needs to be enriched through the development of various types of intelligence at the deepest level possible. If the child has the opportunity to learn through strengths, it will display the changes cognitive, emotional, social and even physical changes were positive and amazing.

\section{EDUCATIVE GAME}

Andang (2006) explains that the game play is a play activity purely for pleasure without seeking to win or lose. Associated with play activities, physical and mental development of children will develop much better than the children who did not much play. In addition, through play moral behavioral development of children will develop better, namely when children develop empathy and understand the rules and the role of civil society. Child playing activities that express the two things that empathy and the rules and the role of civil society to facilitate the process of development of moral behavior in children (Solehuddin, 1997).

One of the activities that can be done by the children is playing an educative game. The educational games are fun educational activities for children; rich in values, norms and ethics. On the other hand, educational games are also useful to develop a variety of children's intelligence so that the potential of children completely excavated and expected to be the actualization for children in the future.

Educational games will carry a child on the nature of positive qualities such as productive, creative, fun, help facilitate teachers teach and train the children character values (Andang, 2006).

Educational games are also very flexible in its application in the classroom. It can be used either in the center of the system, and also classical area, so it will help facilitate teachers to improve the quality of learning in the classroom.

There are 10 (ten) Edugames in this study that the card wants to know, familiarity water, paper honesty, friends helper, leap cooperation, figures introductions, bottles compactness, creative volleyball, hard work ball, and democratic wheels. The descriptions of 10 Edugames above can be seen in the table as follows:

\subsection{Card Wants to Know}

The leader of the game (the teacher) asked participants (kids) to sit in a circle, each participant chose the name of fruits to the nickname (if the theme fruits), the leader game in charge of distributing the card and does not participate in the games, leaders games distributed playing cards one by one to each participant is around, if there is a number or the same image, then the participants to guess the name of the call, participants who first guesses and right, then get a card from losing participants guessed, when the cards dealt by the leader of the game runs so each participant to count cards obtained, participants winner is the participant who collects the most cards.

\subsection{Familiarity Water}

Participants are divided into groups, with each group of at least 10 people, each group chooses one person as the maker of water, each participant must close the hole in the plastic gutter so that water can fill plastic gutter and the ball came out, plastic gutter must be in a state of standing, must not be tilted! Tools for collecting water using the tools provided game leader.

\subsection{Paper Honesty}

Participants make the tail (the tail) of a sheet of paper divided HVS 5-7 longitudinal section, participants write their name on the edges of the paper, Attach the paper that has been named in the belt so as to resemble the tail, after the leader of the game deliver on cue start, each participant mutual take the tail, the tail participants who have taken it to be passive or silent, after the first session time expires, the participant count the tail is obtained, participants count the tail obtained. For participants who still tail then added with a tail that is obtained, the winner of the game is that participants who took the most tail, before continued in the second session, the participants gave the tail obtained to its owner by reading the name on the tail, participants who lost tail must atone by following what is commanded by the participants who took the tail.

\subsection{Friends Helper}

Participants form a circle with adjustable spacing between the participants. If participants are a lot of games (over 10), then made the participants lined up 
with each row just as much. For example, every row 2 , the leader of the game select two participants to do a suit, so known who is so "ucing" (people who chase) and so mice (those being pursued), Leader of the game deliver on cue start, the participants so the cat began chasing a mouse, a rat so participants can be attached in front of the other participants so that will be pursued by a cat is a participant plastered by the rat. Automatic participants were plastered into mice. If plastered ranks berbanjar, then that person automatically becomes the back of a rat and will be chased by cats, in this game there are no winners and losers.

Note: The person who is the rat must be attached in front of the other participants do not behind.

\subsection{Leap Cooperation}

Participants were divided into several groups, each group of 5-10 people, each group line up one row, participants of each group should hold his shoulders are in front and should not be separated, the game leader gives instruction to jump right, left, front, or rear, participants should follow instructions from the leader of the game, and jumped together properly as he was told, the game winner, who either little mistake, I took the game more challenging, the rules changed the participants jump contrary to the instructions of the leader of the game.

\subsection{Figures Introductions}

Participants were told to count to determine the number of participants and number dialing. Every time one of the leaders mentioned figures, the people who have the call numbers stand and say the name, and so on until everyone gets. The mention of numbers is done randomly and can addition or subtraction. If within 3 seconds not mention the name of the seat to move in or out of the participants.

(Name can be customized with the theme of learning).

\subsection{Bottles Compactness}

Game leader divides participants into groups. Each group has a minimum of 5 people. Each group put pencil duties that have been tied five corners or more into the bottle. The rope is tied around the back of the waist. The winning group is the group that most first insert a pencil into the bottle.

\subsection{Creative Volleyball}

Plastic filled with water (a ball), fabric, and plastic rope (net). Participants were divided into two groups, each fabric is held by two people as a pitcher (plastic water), and a ball thrown into the net past the enemy, when the enemy could not catch and throw back (plastic tableware) then points to the team thrower. And so on until the point specified.

\subsection{Hard Work Ball}

Participants were divided into several groups, each group of at least 5 people (more challenging), each group lined up to the distance between the members of one step, each group had to travel a predetermined distance by moving the ball back over the groin, a member of the rearmost after receiving the ball ran straight to the front and stood in front of members who had been standing at the front, then move the ball again through the groin, and so on until a predetermined threshold. The winning group, the group first to the finish line.

\subsection{Democratic Wheels}

Participants were divided into two groups. Each group went into a wheel made of tarp, while rolling the wheel, each group took a ball that is passed by the wheels.

Note: Participants must not get out of the wheel. The most likely group that collected the ball on the winning team.

\section{RESEARCH METHODOLOGY}

The approach used in this study is a quantitative approach with quasi experimental methods, involving 40 children.

Testing the effectiveness of learning programs using a quasi-experimental design. Furthermore, to prove the hypothesis of testing the effectiveness of learning research techniques used in different test average (t-test). Statistical data analysis techniques used are nonparametric statistics. Nonparametric statistics is hypothesis testing procedures that the normality of the distribution was not met, or often referred to as free method of distribution (Furqan, 2004).

Further analysis of the data in this study using the Wilcoxon test. According Furqan (2004) Wilcoxon test is useful to test the behavior, because it can show, among others: (a) a member of which in a couple "greater than", which claimed a distinctive sign of observations in each pair, and (b) make rang 
differences in order to provide absolute price. Furthermore Furqan define in more detail that this test can make a judgment about the "greater than" between the two performances on each pair, also can make a judgment between two different scores arising out of every two couples, and can make a judgment between two different scores arising out of every two couples with giving the order rang. Overall data analysis was performed using SPSS 14.0 for Windows.

\section{RESEARCH RESULT}

The results showed that before treatment in the experimental group showed that the three children who have not appeared plural intelligence, seventeen children who had appeared plural intelligence and wit no child plural developing according to expectations. When depicted in graphic form, then the picture pretest plural intelligence of children in the experimental group presented in graph 1 below.

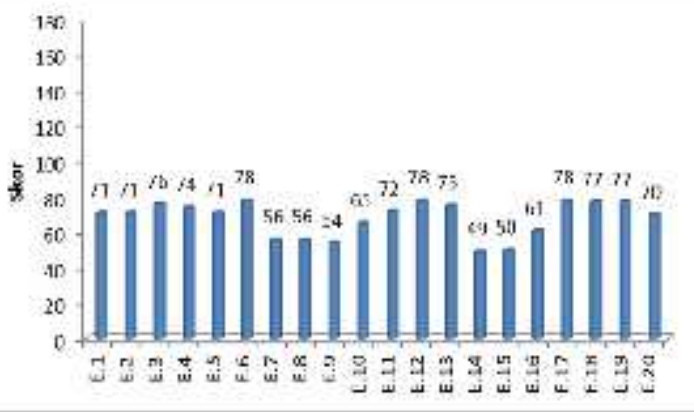

Graph 1. Overview Pretest Multiple Intelligence Children Kindergarten Group Experiments

While in class pretest control based on the results obtained by the results of two children who has not appeared plural intelligence, eighteen children who had appeared plural intelligence and wit no child plural developing according to expectations. When depicted in graphic form, then the picture pretest plural intelligence of children in the experimental group presented in graph 2 below.

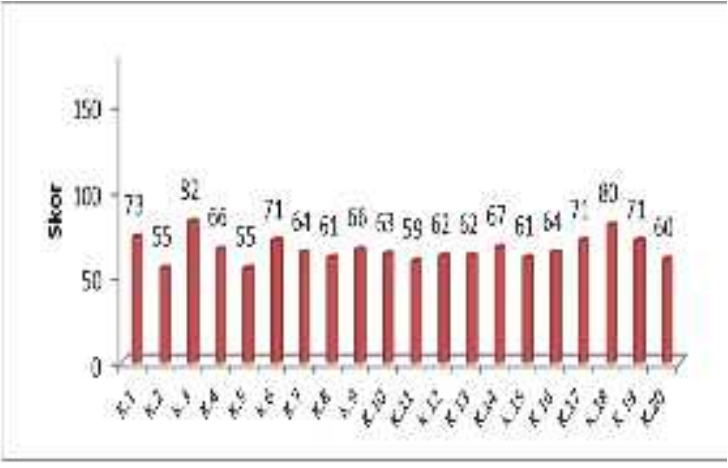

Graph 2. Overview Multiple Intelligences Pretest Kids Kindergarten Control Group

The results showed that before learning activities using educational games plural intelligence applied achievements in the experimental group and the control group tended similar. It is pointed out that the area of children's intelligence in the form of (1) Linguistic intelligence; (2) logical-mathematical intelligence; (3) spatial intelligence; (4) bodilykinesthetic intelligence; (5) musical intelligence; (6) interpersonal intelligence; (7) intrapersonal intelligence; and (8) natural intelligence have no differences.

As for after being given treatment by using learning using educational games in the experimental group there was an increase in plural intelligence achievement; on all intelligence. It is pointed out that the educational games can help develop early childhood plural intelligence.

The results showed that after treatment showed that the plural intelligence of children in the experimental group showed that there were two children who had appeared intelligence plural and there are 18 children whose intelligence plural developing according to expectations and no child who does not appear plural intelligence. This can be seen in graph 3 below.

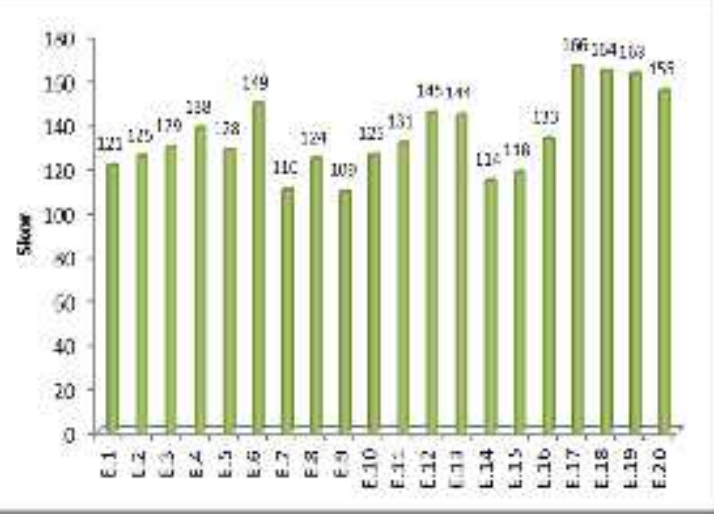

Graph 3. Overview posttest Multiple Intelligence Children Kindergarten Group Experiments 
While in the control group the results showed that at the time of the posttest showed that intelligence obtained plural of children that there are four children who were developing according to expectations plural intelligence, sixteen twelve children who had appeared plural intelligence and wit no child plural yet to emerge. This can be seen in graph 4 below.

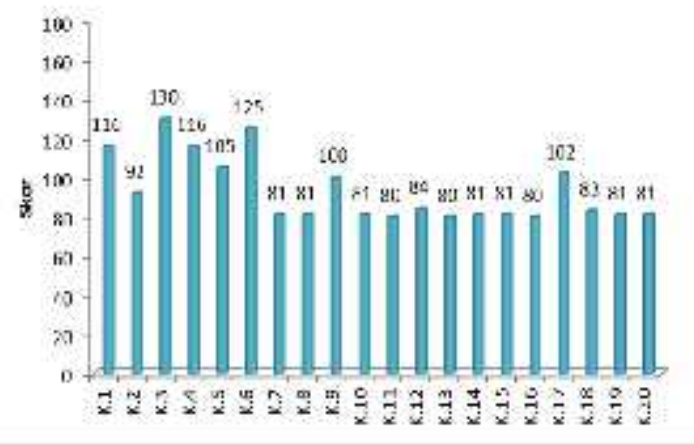

Graph 4. Overview Multiple Intelligences posttest Kids Kindergarten Control Group

Based on the result achieved plural intellectual development of children looks different. However, there were no differences tend to good in experimentation or control group before being given treatment by learning using educational games. After being given a lesson by using educational games in the experimental group there appears to be a difference in the results of the posttest between the experimental group and the control group. This means that the educational games can be used to develop intelligence plural mode early childhood.

\section{CONCLUSIONS}

The conclusion that can be drawn from these results, the teacher should position the child as the center of learning in the learning activities as a whole, especially in efforts to help develop the intelligence of multiple children, whether in the classroom or in the field of play. This means that teachers provide many opportunities for children to actively develop skills and explore all the learning materials without getting a lot of pressure or instruction from the teacher. Subsequent researchers to develop research on multiple intelligence development of children by determining the focus of study on some kind of intelligence alone.

\section{ACKNOWLEDGEMENTS}

This research cannot be separated from the help of other parties in this case Indonesia University of Education on research grants, and its staff who have helped the success of this study.

\section{REFERENCES}

Abraham, S.J. (2001). Multiple Intelligences in the Classroom. Issues in Education, Volume 24, 2001, pp. 1-14.

Andang, I. (2006). Education games (menjadi cerdas dan ceria dengan permainan edukatif. Yogyakarta: Pilar Media.

Armstrong, T. (2003). Sekolah para juara (menerapkan multiple intelegences di dunia pendidikan). Penerjemah: Yudhi Murtanto. Bandung: Penerbit Kaifa.

Campbell, L, et. al. (1996). Teaching and learning through multiple intelegences. Massachusetts: Allyn \& Bacon.

Eliza, D. (2005). Pengembangan Kecerdasan Jamak Dalam Pembelajaran Terpadu di Taman Belajar Mutiara Harapan. Jurnal Pendidikan Anak Usia Dini PPs UNJ. Vol 3. No 3. Hal. 50-74

Furqon. (2004). Statistika terapan untuk penelitian. Bandung: Alfabeta.

Gardner. (2003). Multiple intelegensi (teori dalam praktek). Jakarta: Ineteraksa.

Jamaris, M. (2005). Asesmen Perkembangan Anak Usia Taman Kanak-Kanak Berbasis Kecerdasan Jamak. Jurnal Pendidikan Anak Usia Dini. Volume 3 No. 1 Hal 19-55.

Lwin, M., et.al. (2003). Cara mengembangkan berbagai kecerdasan. Penerjemah: Christine Sujana. Yogyakarta: PT Indeks Kelompok Gramedia.

Musfiroh, T. (2004). Bermain sambil belajar dan mengasah kecerdasan (stimulasi multiple intelegences anak usia taman kanak-kanak). Direktorat Pembinaan Pendidikan Tenaga Kependidikan dan Ketenagaan Perguruan Tinggi Subdit PGTK dan PLB.

Rachmani, F.I. (2003). Multiple intelegences mengenali dan merangsang potensi kecerdasan anak. seri ayah bunda. Jakarta: Aspirasi Pemuda.

Rachmawati, Y. (2005). Musik sebagai pembentuk budi pekerti, sebuah panduan untuk pendidikan. Bandung: Panduan.

Reber, A.S. (1998). The penguin dictionary of psychology. Ringwood Victoria: Penguin Books Australia Ltd. 
Solehuddin, M. (1997). Konsep dasar pendidikan prasekolah. Departemen Pendidikan dan Kebudayaan, Fakultas Ilmu Pendidikan, Institut Keguruan dan Ilmu Pendidikan: Bandung.

Syaodih, E. (2009) Pengembangan alat ukur kecerdasan jamak anak taman kanak-kanak. Laporan Penelitian. Universitas Pendidikan Indonesia. 